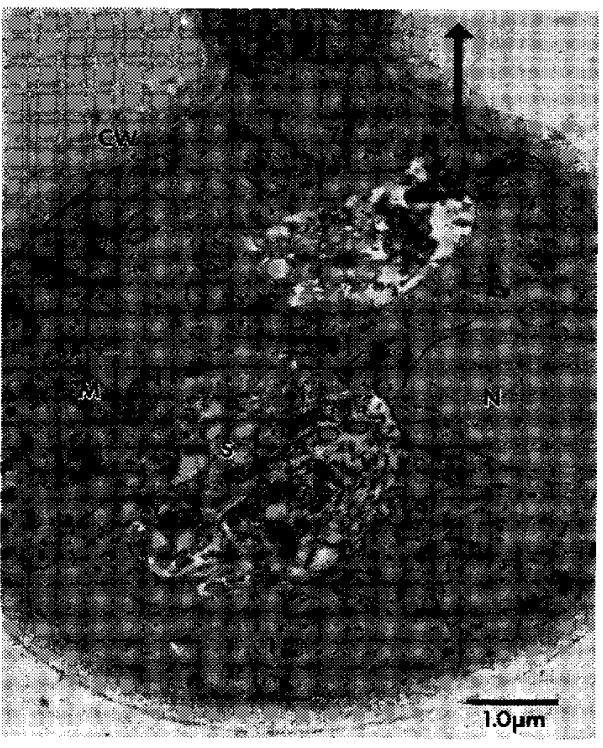

図 1 発牙しているアカパンカビ分生子

$\mathrm{CW}$; 細胞壁, $\mathrm{S}$; 貯蔵顆粒, $\mathrm{N}$; 核

$\mathrm{M}$ ；ミトコンドリア，矢印は発芽の方向

$1)$.

4) さらに発牙がすすむと，それら㬝板状あるいは管 状構造も次第に崩壊し，やがてはその領域が空胞化して しまう.

5 ）貯蔵顆粒はミトコンドリアや紐胞膜と構造的に連 絡しており酸性フォスファターゼの活性領域でもある。

6) 蒸溜水中で発物能をもつ系統 $4 \mathrm{~A}$ 之, 発牙能をも たない系統 $38 \mathrm{a}$ の交配より得られた 140 の $\mathrm{F}_{1}$ では， 5 つの分離株 $(3.6 \%)$ で発芽能をもっていた。系統株 4 Aは子のう胞子色突然変異因子 $(t s)$ をもっており，そ の遗伝子をもつ子のう胞子は発芽できないので，140の $F_{1}$ はすべて，ts 遺伝子に関しては野生型である.した がって分生子の発芽能は, $t s$ 遺伝子(第 5 連鎖群) と連 鎖した遺伝子によって支配されている可能性がある。

7） $\alpha$ 一ナフチルアセテートを基質として，非特異性 エステラーゼの電気泳動パターンをしらべると，系統株 により $3 \sim 5$ つの活性バンドがみとめられる.しかし蒸 溜水中での発芽能とそれら泳動パターンとの間には相関 はない。

8) エステラーゼ活性バンドのうち，少なくとも 1 〜 2つは diisopropyl fluorophosphate によって消失 するととから，細胞内に脂肪族エステルの存在が予測で きる。

9 ）エステラーゼ活性バンドは，分生子の発芽ととも に弱くなり，菌系状細胞ホモジネートでは，ほとんど活 性が消失してしまう。
10）アカパンカビ分生子の液胞には, 酸性ホスファタ 一ゼの活性があることから，リソゾームという解釈もな されているが，貯蔵物質の分解と発芽との閒の関連性か ら, 兑しろ発芽に齐し積極的な意義をもつ貯蔵顆粒と呼 ぶ方がふさわしい。

\section{3. 口腔外科疾患に対するCTの応用}

今里 洋一（松山赤十字・日外）

1972年, 英国の Hounsfield と Ambrose により開 発されたX線コンピュータ一断層撮影装㯰は，乙乙数年 間で飛躍的な普及をみ, 装置の改良々相まって，脳外科 領域のみにとどまらず，身体の各部における応用が行わ れている。

私は，EM I 1010型C Tスキャンナーを用いて，炤和 53年 6 月より, 口腔外科䄈患に応用し，その優れた情報 性を確認したので, 単純X線像と C T 像を比較して症例 を供覽し，併せてC Tおよび1010型の限界についても言 及する。

対象は上顎癌 2 例, 上顎囊胞 3 例, 上頻洞炎 3 例, 上 䫑骨骨折 4 例で, いずれも C T 以外の検査では疾患の性 状や病单の拡がり（範囲）の確定が困難であった12例で ある、C Tの併用により，かなり正確な所見を掝むこと が计来たが，数 $\mathrm{mm}$ 単位の微細な構造の判明は困難であ り，また下箱部の撮影は出来なかった。

\section{4. サル・リンパ球のロゼット形成に関する検討}

○内山 長司・古賀 利枝・後两 正三 （口細）

福田 仁一・山本益四郎・山田 長敬

(1口外)

近年, 実験動物種による細胞免疫学的な検索方法が確 让され，数多くの報告がある．演者らは，日本サルを用 い, 料周証や骨移植時の生体反応を細胞免疫学的に検索 することを目的として,サルのリンパ球の分離（西田ら， 1977）を行い，そのリンパ球に対する Rosette forming cell (RFC)について, sheep, guinea pig, rat, mouse 等の red cell 支用いて検討した. また, RFC の算定は, 從来の算定法と Counter model TA-2 (C CM TA-2) の成續と比較して報告する。

実験方法：サルのリンパ球は Ficoll-Isopaque 混合 
液の遠心分離法（比重1.0721）届用いた，被検動物の 1 \%赤血球は通法のでとくに 4 万倍希釈した.また T cell 測定法（矢田1972），B cell 測定法 (St.jernsward 1972）を用い，いずれの被検体とも CCM TA-2 によ り粒経別体續\%分布を行った。

実験成績：サルの頜 リンパ節リンパ球の回収率は 80 \%，リンパ球の純度は 87\%であった 実験動物の red cell の CCM TA-2 による粒経別体積\%分布結果は， sheep $14.6 \mu^{3}$, guinea pig $21 \mu^{3}$, rat $14 \mu^{3}$, mouse $12.5 \mu^{3}$ にピークが見られた。 また， sheep red cell による REC では, red cell 7-18 $\mu^{3}$, 1ymph cell 20-30 $\mu^{3}$, RFC $33 \mu^{3}$ 以上であった。䫓りンパ節 T cell (RFC) は $33 \mu^{3} 11$ 個, $47 \mu^{3} 9$ 個, $61 \mu^{3} 5$ 個計 RFC は25個, 一方 B cell (RFC) は, $33 \mu^{3} 8$ 個, $61 \mu^{3} 5$ 侗 の計 RFC は13個の粒経別体積数を得た．從来の測定法 では， T cellの RFC は20.5\%，B cellの RFC は 18.3 \%であった，以上の成績から，サルの $1 \mathrm{ymph}$ cell に 対する実験動物の red cell の RFC は, sheep red cell が最も安定した結果を得た。

\section{5. 咽頭弁手術が上顎骨発育におよぼす影響と同手術部 の神経再生について}

○安藤 紳・池尻茂・梶山稔 (2口外)

鼻咽腔の閉鎖機能を改善する方法としての咽頭弁移植 手術は，秀れた治療法であることはすでに知られてい る。しかしながら，手術侵襲による上顝骨の発育障害， あるいは移植部における機能の回復等の問題が残されて いる．そこで演者らはビーグル犬を使用してての種の研 究に着手した。

生後環境に十分順応した 99日〜114日 令のビーグル犬 を使用し，全身麻酔下にて上萃升法咽頭弁移植手術を行 なった。

雌雄共に一週目迄は手術群に体重減少が見られ，15週 目にて対照群に近似值を示すまで回復した。この事は今 後臨床においても慎重な配慮を示唆する所見と思われ る. 術後29週目にペントバルビタール筋肉麻酔下で放血 致死させた。剖検時に内藍, 諸器官に異常は認められな かった。断頭後軟組織を除去し，斉藤の計測点に従い上 下顥骨それぞれについて，霜列幅径，矢状方向の成長在 実測し対照群と比較した。咽頭弁移植手術部位は通法に 従い，パラフィン包理後矢状断にて標本を作製し，へマ
トキシリン・エオジン重染色, Ungewitter の尿素一硝 酸銀法の Powers 変法を本学口腔病理学教室が改良し た神経染色法にて観察した

上下顎骨実測に関しては，手術群が対照群に対して低 值を示す部位も見られたが，例数が少ないので手術の影 響としての結論は今回下していない。

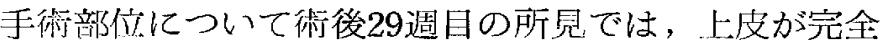
に修復しているものの，筋線維については少数で排列状 態が乱雑であり，瘢痕である事をうかがわせた，粘膜固 有層及び筋層には再生した神経が多数珰められた。

\section{6. ヒト肝臓の Serine-Pyruvate Aminotransferase について}

\section{○高田 義一・野口 知雄 (生化学)}

Serine-pyruvate aminotransferase (SPT) は serine $か ら$ hydroxypyruvate へのアミノ基転移反 応を触媒する B 6 醅素であり, serine からの糖新生に 打ける初発反心念触媒し, 哺乳動物の肝臓に広く分布し ている．ラット肺藏では SPTは peroxisomes と mitochondria の雨画分に分布しており，両画分の酵素 はいずれも約 8 万の分子量及び $\mathrm{pH} 8.0$ の等電点を持ち， pyruvate をアミノ基受容体として多くのアミノ酸に 作用する ${ }^{\prime}$ 。今回, 我々はヒ卜肝臓のSPT が, peroxisomes にのみ存在し，ラットの SPT と異なった性質 を示すととを明らかにした2゙。

1）䳸糖密度勾配遠心法でヒト肝臓を細胞分画する と, SPT は peroxisomes の marker である catalase と同一の分布示した. mitochondria の marker としての glutamate dehydrogenase とは全く 異なった分布を示した。即ち，全活性の65一70\%が密度 $1.25 の$ peroxisome 画分に, 残りが可溶性画分に回収 され, 密度1.18の mitochondria 画分には活性は検出 されなかった。

2) 可溶性画分と peroxisome 画分加 SPT を電 気泳動的に単一まで精製し，比較検討した。両酵素標品 は同一の物理的, 酵素学的性質を示した。性質を以下に 示す：分子量は約 8 万で， 2 個の同一 subunit からな り，8.0-8.50間に至適 $\mathrm{pH}$ を持つ. Pyruvate をア ミノ基受容体とすると serine に対し, 又 serine をア ミノ基供与体とすると pyruvate 亿対して特異性を示 す. serine 及び pyruvate に刘する見かけ上のKmは それぞれ $8.5 \mathrm{mM}$ 及び $1.4 \mathrm{mM}$ である. 